\title{
Pembinaan Keluarga Dalam Perspektif Jamaah Tabligh*
}

(COACHING FAMILY IN TABLIGHI JAMAAT)

\author{
Kamalludin \\ Fakultas Agama Islam Universitas Ibn Khaldun \\ Jl. KH. Sholeh Iskandar Bogor Jawa Barat \\ E-mail: kamalludin06@gmail.com
}

\begin{abstract}
Khuruj in Tablighi Jamaat are madrassas preaching trip to establish the nature of the self gradually imaniyyah culprit. Expected to experience this propaganda effort, the help of God will always be there at any time and the cause of God's guidance for the universe will end up with Khusnul Khatimah. But in practice it takes a balance between preaching and family coaching. Because Khuruj requires one to come out leaving his family in a certain time frame. So then it takes a balance between preaching and coaching families, in addition to the support of his wife and children to overcome various problems at the time the head of the household was Khuruj Fi Sabilillah.
\end{abstract}

Keywords: Tablighi Jamaat, Khuruj, Foster Family

\begin{abstract}
Abstrak: Khuruj dalam Jamaah Tabligh merupakan madrasah perjalanan dakwah guna membentuk sifat imaniyyah secara bertahap pada diri pelakunya. Diharapkan dengan pengalaman usaha dakwah ini, maka pertolongan Allah akan selalu ada setiap saat dan menjadi sebab hidayah Allah bagi seluruh alam hingga akan berakhir dengan Khusnul Khatimah. Tetapi dalam pelaksanaannya dibutuhkan keseimbangan antara dakwah dan pembinaan keluarga. Karena Khuruj mengharuskan seseorang untuk keluar meninggalkan keluarganya dalam rentang waktu tertentu. Sehingga kemudian dibutuhkan keseimbangan antara dakwah dan pembinaan keluarga, selain adanya dukungan dari istri dan anak untuk mengatasi berbagai permasalahan di saat kepala rumah tangga sedang Khuruj Fi Sabilillah.
\end{abstract}

Kata Kunci: Jamaah Tabligh, Khuruj, Pembinaan Keluarga

${ }^{*}$ Diterima tanggal naskah diterima: 22 Mei 2014, direvisi: 28 Mei 2014, disetujui untuk terbit: 26 Juni 2014. 


\section{Pendahuluan}

Khuruj atau perjalanan dakwah dalam bilangan waktu yang lama secara istiqomah membutuhkan tidak hanya pengorbanan materi saja, namun immateri. Sebagai contoh, ketika seorang karkun (karyawan Alquran; istilah Bagi Anggota Jamaah Tabligh) menyambut takaza (setelah nisabnya sampai) untuk khuruj selama 40 hari, secara sistematis ia akan meninggalkan keluarga selama 40 hari tersebut, itu artinya ia harus mengabaikan salah satu kewajibannya terhadap keluarga, yakni pembinaan dan pemeliharaan kesejahteraan keluarga dalam bentuk nafkah. Nafkah dalam pengertian luas tak hanya dalam bentuk materi (sandang, pangan, papan) namun juga berupa kebutuhan keluarga akan rasa kasih sayang, penghargaan, perlindungan ataupun kebutuhan biologis seorang istri dan lain sebagainya.

Allah S.W.T berfirman dalam surat ath-Thalaq ayat 6:

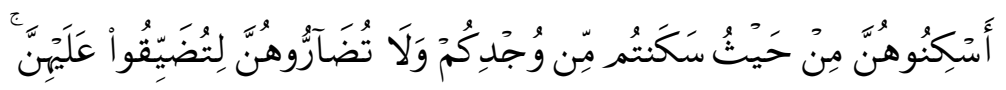

Tempatkanlah mereka (para isteri) di mana kamu bertempat tinggal menurut kemampuanmu dan janganlah kamu menyusahkan mereka untuk menyempitkan (hati) mereka. (QS. at-Thalaq: 6).

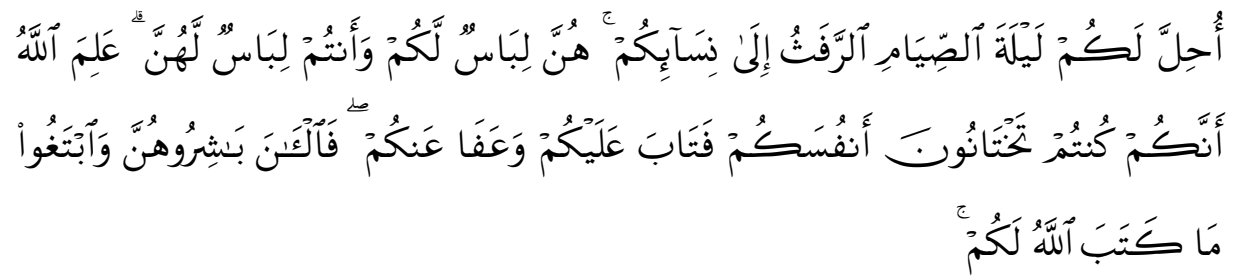

Dihalalkan bagi kamu pada malam hari bulan puasa bercampur dengan isteriisteri kamu; mereka adalah pakaian bagimu, dan kamupun adalah pakaian bagi mereka. Allah mengetahui bahwasanya kamu tidak dapat menahan nafsumu, karena itu Allah mengampuni kamu dan memberi ma'af kepadamu. Maka sekarang campurilah mereka dan ikutilah apa yang telah ditetapkan Allah untukmu. (QS. al-Baqarah: 167).

Dalam hadits yang diriwayatkan oleh Abu Hurairah ra, Rasulullah Saw. bersabda: "Keluarga sebagai unit sosial terkecil memiliki peran yang sangat menentukan di masyarakat." 
Menurut M. Quraish Shihab, "keluarga adalah jiwa masyarakat dan tulang punggungnya,"1 sehinggga atau tidaknya suatu masyarakat tergantung dari baik tidaknya keluarga-keluarga yang ada pada masyarakat tersebut.

Keluarga berperan sebagai pembentuk generasi masa depan yang lebih baik dan berkualitas, karena itu pembinaan keluarga sangat besar artinya dalam upaya pembentukan watak dan kepribadian muslim yang kuat dan sehat, baik fisik maupun mental, pembinaan keluarga juga akan membentuk rumah tangga yang sakinah, mawaddah dan rahmah sebagaimana yang diimpikan seluruh anggota dalam keluarga.

Prioritas dakwah dan pengorbanan yang ditekankan pada setiap karkun seringkali terbentur dengan berbagai masalah keluarga yang timbul, sebab tanpa disadari kadang melalaikan hal-hal yang dibutuhkan keluarga. Karena sesungguhnya bila kita pahami esensi dari dakwah yaitu, kegiatan yang dapat memberikan solusi Islam untuk semua problematika yang ada dan mencakup semua aspek, maka sebuah aktifitas dakwah yang dilakukan seorang suami tanpa pemahaman Islam secara kaffah dan pertimbangan matang terkait kehidupan dalam keluarga, kemungkinan akan menimbulkan masalah dan bukan menyelesaikan masalah, bukanlah dakwah seharusnya berada pada posisi solusi? Baik solusi ekonomi, sosial, politik, budaya, keluarga dan sebagainya. Jadi amatlah ironis bagi seorang dai yang mengorbankan diri untuk umat, sementara disisi lain keluarga kurang diperhatikan pembinaanya.

\section{Metode Dakwah Khuruj}

Mengamalkan agama dan menyeru manusia agar taat kepada Allah adalah kewajiban setiap umat Islam. Dakwah adalah tugas para nabi, dan Rasulullah adalah sebaik-baik nabi terakhir, dan umat ini adalah sebaik-baik umat dan umat terakhir. Tugas dakwah ini ditugaskan kepada kita sebagai umat akhir zaman, sebagaimana firman Allah Swt. dalam Alquran surat Ali Imran 110:

${ }^{1}$ M. Quraish Shihab, Membumikan Al-Qur'an, (Bandung: Mizan, 1996), hlm., 253 


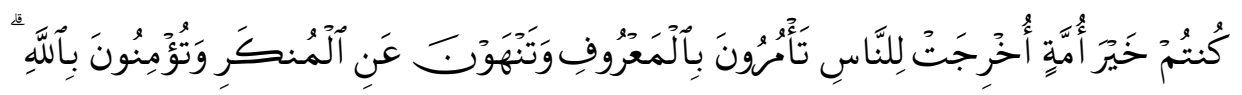

Kamu adalah umat yang terbaik yang dilahirkan untuk manusia, menyuruh kepada yang ma'ruf, dan mencegah dari yang munkar, dan beriman kepada Allah. (QS. Surat Ali Imron: 110).

Maulana Ilyas salah satu seorang tokoh Jamaah Tabligh mengatakan bahwa maksud lafazh ukhrijat adalah memberi isyarat pada suatu tempat untuk benar-benar membuat suatu usaha. Sekalipun kita tidak bekerja. Tetapi sekurang-kurangnya perlu untuk memberangkatkan jamaah khuruj. Tugas kita adalah amar ma'ruf nahi munkar. Lebih lanjut dikatakan "dengan amar ma'ruf nahi munkar, keimanan kalian akan bertambah. Jika tidak melakukannya, maka iman tidak akan meningkat. Oleh karena itu, harus berniat untuk mengambil manfaat darinya," 2

Sebagaimana firman Allah dalam surah Ash Shaff ayat 14:

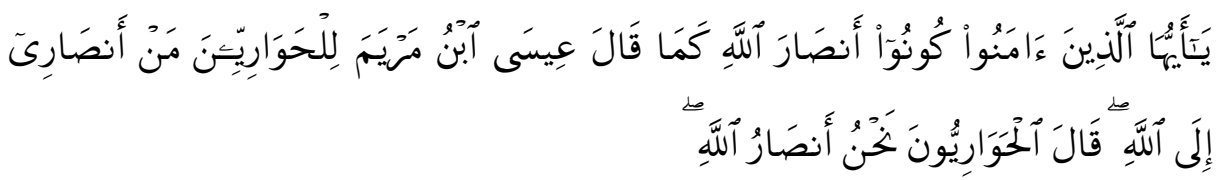

Hai orang-orang yang beriman, jadilah kamu penolong (agama) Allah sebagaimana Isa Ibnu Maryam telah berkata kepada pengikut-pengikutnya yang setia: "Siapakah yang akan menjadi penolong-penolongku (untuk menegakkan agama) Allah?" Pengikut-pengikut yang setia itu berkata: "Kamilah penolong-penolong agama Allah." (QS. Surat Ash Shaff: 14).

Rasul telah berhasil membangun suatu tatanan kehidupan yang sangat mulia dalam sejarah peradaban manusia yaitu kehidupan beragama yang sempurna, karena itulah Rasul pernah bersabda:

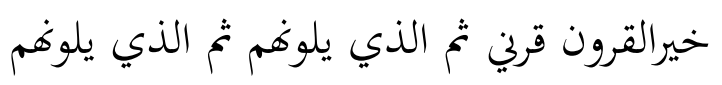

“Sebaik-baiknya masa adalah generasiku (nabi dan para sahabat R.A), kemudian yang setelah mereka (tabi'in), kemudian yang setelah mereka (tabi'ut tabi'in)." (HR. Bukhari dan Muslim).

Ketika itu para sahabat benar-benar mencintai dan mengikuti keteladanan nabi semaksimal dan semampu mereka. Berbeda dengan saat ini,

\footnotetext{
${ }^{2}$ Maulana Muhammad Mansyur dan Mufti Rusyn Syah Qasimi, Mutiara Nasihat Maulana Ilyas dan Maulana Yusuf, (Bandung: Pustaka Ramadhan, 2004), hlm., 1
} 


\section{Kamalludin}

dimana umat Islam mudah mengaku mencintai nabi, namun tak mampu menunjukkan bukti kecintaannya. Cinta Rasul hanya dijadikan senandung, tetapi tak memahami hakekat cinta, karena tak melaksanakan perintah kekasihnya. Mencintai rasul bukan sekedar menghidupkan sunnah shurah (penampilan dhahir) nabi Saw., tetapi sesungguhnya tanda cinta adalah meneruskan kerja dakwah Rasul sebagai siirah (maksud dan tujuan) hidup dan siirah (pikir dan risau) nabi Saw.

Jadi, khuruj merupakan madrasah perjalanan dakwah guna membentuk sifat imaniyyah secara bertahap. Diharapkan dengan pengalaman usaha dakwah ini pertolongan Allah akan ada setiap saat dan menjadi asbab (sebab-sebab) hidayah Allah bagi seluruh alam hingga akan berakhir dengan Khusnul Khatimah.

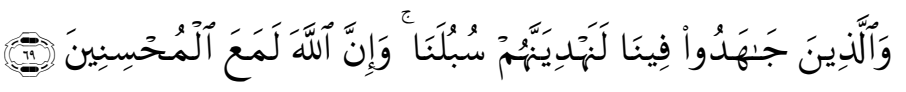

“Dan orang-orang yang berjihad untuk (mencari keridhaan) Kami, benarbenar akan Kami tunjukkan kepada mereka jalan-jalan kami. Dan Sesungguhnya Allah benar-benar beserta orang-orang yang berbuat baik". (QS. Al-Ankabut: 69)

Dalam jamaah tabligh, terdapat 13 asas-asas dakwahnya sebagai berikut: 1). Infirodi, bukan pertemuan besar-besaran, 2). Risau, bukan pikir tinggi-tinggi, 3). Gerak (qadam), bukan tulisan (qalam), 4). Persatuan (ittihad), bukan perpecahan (ikhtilaf), 5). Amar ma'ruf, bukan nahi munkar, 6). Musyawarah, bukan perintah (amar), 7). Senyap-senyap (istitar), bukan propaganda/gembar gembor (isytihar), 8). Kabar gembira (tabsyir) bukan kabar buruk (tanfir), 9). Perdamaian, bukan peperangan, 10). Ringkas (ijmal), bukan mendetail (tafsir), 11). Akar (ushul), bukan ranting (furu'), 12). Rendah hati (tawadhu), bukan sombong (ananiah), 12). Diri sendiri (jaan), bukan harta (maal).

Sedang ushul-ushul (dasar-dasar) dakwah jamaah tabligh yaitu: a). Tentang empat hal yang harus diperbanyak: (1). Dakwah ilallah, (2). Ta'lim wa ta'alum, (3). Dzikir wal ibadah, (4). Khidmat. b). Tentang empat hal yang dikurangi: (1). Makan dan minum, (2). Tidur dan istirahat, (3). Keluar dari masjid, (4). Pembicaraan dan perbuatan yang sia-sia. c). Tentang empat yang harus ditinggalkan: (1). Mengharap kepada makhluk, (2). Meminta kepada makhluk, (3). Boros dan mubazir, (4). Memakai barang orang lain tanpa izin. d). Tentang empat hal yang tidak boleh disentuh: (1). Politik baik luar 
maupun dalam negeri, (2). Khilafiyyah (perbedaan pendapat dalam fiqih), (3). Membicarakan aib seseorang atau masyarakat, (4). Meminta sumbangan dan membicarakan status sosial (pangkat dan jabatan). e). Tentang empat hal yang harus didekati: (1). Ulama, (2). Ahli dzikir, (3). Penulis kitab, (4). Juru dakwah. f). Tentang empat hal yang harus dijauhi: (1). Merendahkan, (2). Mengkritik, (3). Menolak, (4). Membanding-bandingkan. g). Tentang empat hal yang harus dijaga: (1). Taat kepada amir, (2). Mendahulukan amal ijtima'i dari pada infirodi, (3). Kehormatan masjid, (4). Sabar dan tahan uji. Semua asas dakwah dan dua puluh delapan ushul dakwah tersebut adalah hal-hal yang harus diingat, dijaga dan diamalkan ketika khuruj.

Adapun materi yang selalu disampaikan dan ditekankan ketika khuruj sebagai prinsip pokoknya yang dikenal dengan enam sifat sahabatnya yaitu:

a. Yakin pada kalimat Thoyyibah للإله الا الله محمرسول الله "Tiada Tuhan selain Allah dan Muhammad rasulullah."

Sifat yang paling utama adalah sifat iman yakni keyakinan Allah adalah al-Khaliq dan al-Malik yang menguasai alam semesta beserta isinya, makhluk tidak dapat memberi manfaat dan mudharat tanpa izin Allah. Menetapkan dan meyakini bahwa Allah yang mengurus dan mengatur semua makhluk dan menyakini tiada yang patut di sembah kecuali Allah Swt..

Wujud dari keyakinan ini adalah keimanan pada rukun iman, dan cara mendapatkan sifat yakin ini adalah dengan berusaha mengamalkan sunnah rasulullah secara keseluruhan dalam kehidupan sehari-hari selama 24 jam, yaitu terdiri dari: 1). Shurah (bentuk rupa atau penampilan dhahir) Rasul, 2). Sirah (perjalanan hidup) Rasul, 3). Sarirah (pikir dan kerisauan) Rasul. ${ }^{3}$

\section{b. Shalat khusu dan khudhu'}

Shalat merupakan hubungan langsung antara seorang hamba dengan khaliqnya, maka dalam shalat diperlukan konsentrasi pikiran, hati dan perasaan serta seluruh anggota badan tawajjuh kepada Allah agar timbul rasa akan pengawasan Allah, dapat merasakan keagungan-Nya dan bukti syukur akan segala nikmat yang diberi. Itulah yang dimaksud dengan khusuk disini. Adapun khudu ialah merendahkan diri sebagai tanda kepatuhan, tunduk terhadap kebesaran Allah Swt..

${ }^{3}$ An Nadhr M. Ishaq, Khuruj Fi Sabilillah, Sarana Tarbiyah Ummat Untuk Membentuk Sifat Imaniyyah, (Bandung: Al-Ishlah Press, tt), hlm., 107. 
Ketika seorang hamba melakukan shalat secara khusu dan khudu maka akan terbawa sifat ketaatan dalam hidup kesehariannya. Sebagai contoh, ketika shalat kita menundukan pandangan, sehingga tak sempat melihat pada hal yang dilarang Allah Swt. ketika shalat kita memuji kebesaran Allah, bukan membicarakan kehebatan makhluk. Ketika shalat kita menutup aurat, maka diluar shalatpun demikian.

Ketika seorang hamba mampu mengamalkan ini, maka Allah akan memberi jaminan lima hal baginya yakni; 1). Allah akan menghilangkan kesempitan hidupnya di dunia dengan memberi kemudahan dan keberkahan rizki, 2). Allah akan membebaskan dari azab kubur, 3). Akan diberikan kitab catatan amal melalui tangan kanan, 4). Ia akan melintasi titian shirat secepat kilat, 5. Ia akan masuk surga tanpa hisab.

\section{c. Ilmu dengan Dzikir}

Ilmu dan dzikir kesatuan yang tak dapat dipisahkan. Ilmu ibarat jalan dan dzikir adalah cahayanya. Apabila berjalan di dalam kegelapan tanpa cahaya, maka ia akan tersesat. Yang dimaksud dengan ilmu disini ialah seluruh wahyu yang diturunkan oleh Allah Swt.kepada Rasulullah Saw.

Ilmu yang sebenarnya adalah ilmu untuk mengenal Allah dan bagaimana cara berhubungan dengan Allah, sehingga menjamin manusia kelak bisa menjawab pertanyaan dari Munkar dan Nakir dan juga pertanyaan Allah di padang Mahsyar. Rasulullah Saw. bersabda:

$$
\text { اكثرهم ذكرا للموت وأكثرهم استعدادا للموت قبل نزول الموت أولئك هم الاكياس. }
$$

“Orang yang paling pandai adalah orang yang paling banyak mengingat mati, dan paling banyak mempersiapkan (bekal) untuk kehidupan setelah mati sebelum kematian menjemputnya.: (HR. Ibnu Majah dan Ath Thabrani)

Dzikrullah bermakna mengingat Allah. Adapun keutamaan dzikir diantaranya; 1). Allah akan mengingat hamba-Nya yang selalu ingat padaNya, 2). Pemisah orang yang berdzikir dengan yang tidak adalah seperti orang yang hidup (karena selalu berdzikir) dengan orang yang mati (karena tak pernah berdzikir).

\section{d. Ikramul Muslimin}

Ikramul Muslimin adalah menunaikan hak-hak sesama muslim, tanpa mengharapkan hak-haknya ditunaikan, dengan berakhlak baik terhadap manusia maupun makhluk yang lain. 
Sifat ikram yang terendah adalah bersabar dan tidak merepotkan orang lain, karena menyusahkan orang lain akan merusak amal kita dan di akherat akan diminta pertanggung jawabannya. Sedangkan ikram yang paling tinggi adalah mengajak orang lain untuk taat kepada Allah Swt. agar selamat dari azab Allah di dunia dan akherat.

Rasulullah Saw. bersabda:

$$
\text { لا يؤمن أحدكم حتى يحب لأخيه ما يحب لنفسه }
$$

"Tidak sempurna iman seseorang diantara kamu sekalian sehingga kamu mencintai (kebaikan) saudaranya (sesama muslim) seperti mencintai (kebaikan) itu untuk dirinya sendiri," (HR. Bukhari dan Muslim)

$$
\begin{aligned}
& \text { من نفس عن مؤمن كربة من كرب الدنيا نفس الله عنه كربة من كرب يوم القيامة. ومن } \\
& \text { يسرعلى معسر يسر الله عليه في الدنيا والاخرة. ومن يسر مسلما يتره الله في الدنيا } \\
& \text { والاخرة والله في عون العبد مادم العبد في عون أخيه. }
\end{aligned}
$$

"Barangsiapa memberi kelonggaran kepada seorang muslim dari kesulitan dunia, maka Allah pasti memberikan kelonggaran kepada dia dari kesulitan pada hari kiamat, barangsiapa memberi kemudahan pada orang yang mendapatkan kesyukuran, maka Allah pasti memberikan kemudahan kepadanya di dunia dan akherat. Barangsiapa menutup aib seorang muslim, maka Allah akan menutup aibnya di dunia dan akherat' dan Allah selalu menolong hamba-Nya selama hamba-Nya itu menolong saudaranya," (HR. Muslim dari Abu Hurairah)

\section{e. Tashihun-Niyat}

Tashihun-Niyat adalah meluruskan, memperbaiki dan membersihkan niat, pada awal beramal dan sesudah beramal. Ikhlas yang merupakan suatu rahasia antara hamba dengan Rabb-Nya saja, bahkan malaikat pun tak bisa mengetahuinya, ikhlas adalah ruh atau jiwa dari seluruh amal ibadah.

Rasulullah S.A.W bersabda:

$$
\text { إن الله عز وجل لا يقبل من العمل الا ما كان له خالصا وابتغي به وجهه }
$$

"Sesungguhnya Allah Azza Wajalla tidak menerima suatu amal kecuali jika dikerjakan murni karena-Nya dan hanya mengharap keridhaan-Nya." (HR. Abu Dawud dan An Nasa'i). 
Ikhlas adalah: "mengosongkan hati dari seluruh motivasi dunia dalam amal akhirat."

\section{f. Dakwah dan Tabligh}

Dakwah artinya mengajak dan tabligh artinya menyampaikan. Mengajak manusia taat kepada Allah dan Rasul-Nya dengan niat istilah diri agar keimanan dan keyakinan kepada Allah semakin bertambah, sehingga Allah Swt. memelihara diri dan seluruh umat manusia. Allah berfirman:

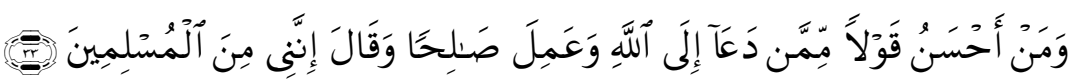

"Siapakah yang lebih baik perkataannya daripada orang yang menyeru kepada Allah, mengerjakan amal yang saleh, dan berkata: "Sesungguhnya aku termasuk orang-orang yang menyerah diri?" (QS. Fushilat: 33).

Dengan usaha dakwah, berarti kita belajar menghidupkan agama secara sempurna dalam kehidupan sehari-sehari sesuai sunnah rasul yaitu:

1) Mengubah keyakinan dari yakin kepada makhluk menjadi yakin hanya kepada Allah Swt..

2) Mengubah maksud dan tujuan hidup, dari maksud dan tujuan hidup untuk dunia, menjadi maksud dan tujuan hidup untuk akherat.

3) Mengubah jazbah (semangat kerja), dari semangat mengumpulkan harta benda dunia, menjadi semangat mengumpulkan amal-amal akherat.

4) Membangun hidup dengan amal, sehingga shalat dan ibadah yang dilakukan memiliki ruh yang bermanfaat dalam kehidupan seharihari.

5) Mengubah akhlak manusia seperti akhlak Rasulullah dan sahabat. ${ }^{4}$

Untuk mendapatkan semua ini, maka parlu meluangkan waktu di jalan Allah dengan harta dan diri sendiri, yaitu istiqomah khuruj minimal tiga hari setiap bulan, 40 hari setiap tahun dan empat bulan seumur hidup. Serta menyempurnakan amal maqomi dan berdoa agar dihantar keseluruhan alam.

Siapapun yang menginginkan kesukseskan, maka dia akan mengikuti orang-orang yang telah sukses di dunia dan akherat, sehingga Allah Swt.. memberi gelar radiallahu anhum kepada mereka. Padahal kehidupan mereka

${ }^{4}$ Shahab, Khuruj, hlm., 139 
jauh dari sentuhan teknologi dan rekayasa industri yang canggih. Mereka memperoleh kesuksesan karena telah berusaha membentuk iman yang sempurna dengan Alquran dan Al-Sunnah. Kesempurnakan iman para sahabat r.a terbentuk bukan dari buku, majalah, Koran, televisi, dan lain sebagainya. ${ }^{5}$

\section{Program (kegiatan) dalam Khuruj}

Adapun program yang biasa dilakukan ketika khuruj, diantaranya adalah:

Pertama; Bayan shubuh, yaitu menyampaikan ceramah kepada jamaah terutama tentang amar ma'ruf, tentang iman dan amal sholeh yang ditugaskan adalah siapa saja yang merasa mampu untuk menyampaikan, tapi yang utama adalah orang yang pernah keluar (khuruj) baik pernah khuruj tiga hari, 40 hari maupun 4 bulan.

Kedua; Ta'lim pagi, yaitu membacakan kitab fadhillah amal, waktunya sekitar pikul 09.00-11.30. Adapun yang dibahas dalam kitab fadhillah amal itu adalah: fadhillah shalat, fadhilah Alquran, fadhillah tabligh, fadhillah sedekah, fadhillah zakat, fadhillah ramadhan, bab tentang keruntuhan umat serta kisah-kisah rasul dan sahabat.

Ketiga; Ta'lim dzuhur, waktunya sekitar jam 12.30 - 13.00.

Keempat; Ta'lim ashar, sambil muzakarah (saling mengingat) tentang enam sifat sahabat, waktunya sekitar pukul 15.30 - 16.00.

Kelima; Jaulah, yaitu berkeliling ke rumah-rumah masyarakat untuk mengajak mereka shalat berjamaah di mushollah atau masjid yang kedatangan jamaah tabligh.

Keenam; Bayan maghrib, yaitu menyampaikan ceramah kepada jamaah yang hadir dalam shalat berjamaah. Setelah itu mereka ditasykil (bujuk) hatinya supaya ikut khuruj tiga hari atau 40 hari ataupun ada yang ingin khuruj 4 bulan, lalu nama-nama mereka dicatat.

Ketujuh; Ta'lim akhir, yaitu membacakan kitab fadhillah amal, waktunya dari jam 21.00-21-30 menjelang tidur sambil muzakarah tentang

${ }^{5}$ Shahab, Khuruj, hlm., 101 


\section{Kamalludin}

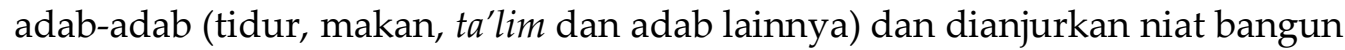
malam untuk melakukan shalat tahajud. ${ }^{6}$

Selain khuruj yaitu kegiatan yang dilakukan jamaah laki-laki (jamaah tabligh), ada juga kegiatan yang disebut masturah yang artinya yang ditutup, yakni istilah bagi wanita kalangan jamaah tabligh yang ditutup secara sempurna (aurat) anggota badannya yaitu dengan menggunakan purdah atau cadar pada wajahnya. Dalam pelaksanaan dakwahnya (jamaah masturah ini) harus disertai mahrom, baik suami ataupun saudara laki-lakinya. Sedangkan kegiatan yang dilakukan jamaah masturah tak banyak berubah dengan apa yang dilakukan oleh jamaah khurujnya (jamaah laki-laki jamaah tabligh) hanya berbeda pada program jaulah, karena program ini (jaulah) hanya khusus dilakukan oleh jamaah khuruj.

\section{Sejarah Jamaah Tabligh}

Jamaah tabligh didirikan di benua India, tepatnya di kota Sahal Nufur, mentablighkan atau menyampaikan risalah keimanan diajarkan sebagai cara dalam dakwahnya. Pendirian jamaah ini diilhami dari mimpi tentang tafsir firman Allah:

$$
\text { كنتم خير أمة أخرجت للناس ... }
$$

"Kalian adalah umat yang terbaik yang dilahirkan untuk manusia."

Makna "ukhrijat" adalah: keluar untuk mengadakan perjalanan (siyahah) dan penyampaian dakwah kepada umat manusia. Dari sinilah awal mula istilah jamaah Tabligh, yang dijadikan khittah perjalanan dakwah oleh pendirinya.

Pendiri jamaah ini ialah Muhammad Ilyas bin Syekh Muhammad Ismail, yang bernasabkan Hanafi. Dia lahir tahun $1303 \mathrm{H}$ dan wafat tahun 1364 H. Semasa hidupnya ia seorang komandan pasukan militer di Pakistan yang bertugas mendalami ilmu diniyah yaitu salah satu tharekat yang memiliki banyak pengikut di benua India, beliau juga seorang hafidh Qur'an.

Penyebarannya jamaah ini mulai di India dan Pakistan, kemudian mencapai negara-negara Arab dan negeri-negeri Islam lainnya. Hingga jamaah ini mempunyai markas-markas dan dai-dai di negeri-negeri tersebut.

${ }^{6}$ M. Iskandar Muda, Wawancara Langsung, 26 maret 2012 
Tak hanya itu, gerakan jamaah ini pun mencapai negara-negara non Islam. Di sanalah jamaah ini mempunyai kegiatan untuk memperkenalkan Islam dan berdakwah kepadanya. $^{7}$

\section{Keutamaan Khuruj}

Banyak kelebihan yang diberikan Allah kepada siapa saja yang keluar di jalan Allah untuk melakukan usaha dakwah, diantaranya:

1. Apabila seseorang keluar dari rumahnya selangkah saja dalam rangka khuruj, maka Allah akan mengampuni dosa-dosanya.

2. Satu perkara yang digunakan untuk menyeru manusia untuk taat pada Allah, maka Allah akan memberinya pahala satu tahun ibadah.

3. Doa orang yang keluar di jalan Allah akan dikabulkan.

4. Setiap rupiah uang yang digunakan untuk keluar di jalan Allah, maka Allah akan memberinya ganjaran 700.000 ganda.

5. Sepagi dan sepanjang khuruj Fi Sabilillah lebih berharga daripada dunia dan segala isinya.

6. Debu-debu yang melekat di tubuh atau pakaian orang yang keluar di jalan Allah akan terhalang dari asap api Neraka.

7. Surga terdiri dari 100 tingkat. Yang paling atas adalah untuk para nabi dan satu tingkat di bawahnya khusus untuk orang yang keluar di jalan Allah.

8. Seorang wanita yang ridha suaminya khuruj Fi Sabililla, maka Allah akan memasukkan wanita itu 500 tahun lebih terdahulu daripada suami mereka, dan ia akan menghiasi dirinya dan menunggu kedatangan suaminya di pintu surga. ${ }^{8}$

\section{Hakekat dakwah Islamiyah}

Komitmen seorang muslim pada dakwah Islam tak hanya dengan menyampaikan dakwah melalui lisan saja, namun ia juga hanya menjadikan

${ }^{7}$ Nizar bin Ibrahim al-Jarbu, Peringatan Penting Terhadap Jamaah Tabligh, terj, Arif Mufid, (Surakarta: Yayasan al-Madinah, 1998), hlm. 4.

8 Maulana Muahammad manshur, Masturah, Usaha Dakwah di Kalangan Wanita, (Bandung: Pustaka Ramadhan, 2001), hlm., 91. 


\section{Kamalludin}

dirinya contoh hidup dari apa yang diserukannya melalui lisannya, sekaligus memberikan gambaran Islam sejati melalui keterikatannya secara benar dengan Islam itu sendiri.

Allah S.W.T berfirman:

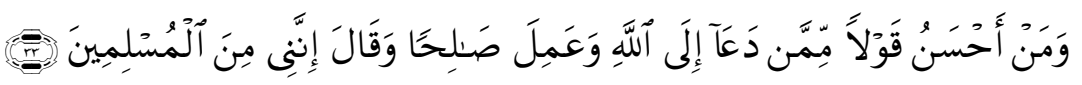

Siapakah yang lebih baik perkataannya daripada orang yang menyeru kepada

Allah, mengerjakan amal yang saleh, dan berkata: "Sesungguhnya aku Termasuk orang-orang yang menyerah diri?" (QS. Fushilat:33 ).

Menyeru manusia kejalan Allah S.W.T merupakan kewajiban sekaligus ibadah yang bias mengantarkan pelakunya untuk dekat (taqarrub) dengan Allah, sehingga Allah akan mengangkat kedudukannya di dunia dan akhirat.

Dakwah merupakan pilar yang kokoh dan perkara yang dinamis dalam Islam. Keberlangsungan dakwah Islam akan menjamin adanya pengaruh dan penyebaran Islam itu sendiri. Artinya, usia dakwah sangat menentukan usia Islam; yakni sejak kemunculannya sampai Allah mewariskan bumi dan para penghuninya untuk Islam. Oleh karena itu, dakwah Islam wajib terus disosialisasikan di tengah-tengah umat Islam bahkan wajib dijadikan prioritas dalam pikiran mereka, tentunya sesuai dengan kapasitas kemampuan individu masing-masing.

Sejarah telah menjelaskan keberhasilan dakwah yang dilakukan oleh Rasulullah, saat itu terjadi perubahan menyeluruh dalam kehidupan masyarakat yang meliputi berbagai bidang kehidupan yang sebelumnya jahiliyyah menjadi terbimbing dengan nilai-nilai Islam. Keberhasilan itu tak lain karena Rasulullah adalah orang yang paling tahu tentang permasalahan dakwah yang tampak dari fenomena kehidupan masyarakat pada waktu itu. Disamping itu juga karena rasulullah dalam dakwahnya selalu mendapatkan tuntunan dari wahyu yang diturunkan oleh Allah melalui perantara malaikat Jibril.

Allah Swt. berfirman:

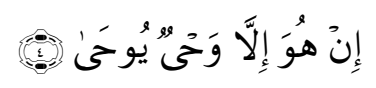

Ucapannya itu tiada lain hanyalah wahyu yang diwahyukan (kepadanya) (QS. An-Najm: 4). 
Atas dasar itulah Rasul menjadi teladan dalam semua hal, maka demikian pula halnya dengan perkara dakwah ini.

Pada dasarnya dakwah yang dilakukan oleh Rasulullah dan para rasul sebelumnya mempunyai misi yang sama yaitu menyeru pada kalimat tauhid Laa Illaha Illallah Muhammadur Rasulullah, sebagaimana dinyatakan dalam Qur'an:

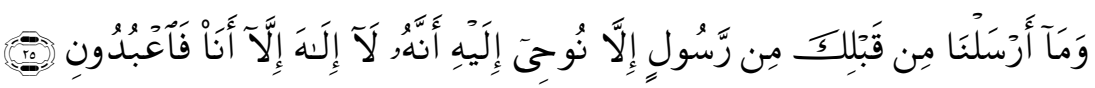

Dan Kami tidak mengutus seorang Rasulpun sebelum kamu melainkan Kami wahyukan kepadanya: "Bahwasanya tidak ada Tuhan (yang hak) melainkan $\mathrm{Aku}$, Maka sembahlah olehmu sekalian akan aku" (QS. Anbiya: 25).

Karena dakwah yang dilakukan oleh para dai di sepanjang masa adalah mengajak pada kalimat tauhid sebagai pondasi pertama. Dakwah inilah yang pertama sekali dilakukan oleh nabi Muhammad pada periode makkiyah di kota Mekkah, dan ini tidak berhenti sampai periode selanjutnya.

Berdakwah pada masyarakat Islam, yang sudah jelas mengaku Tuhan yang satu yaitu Allah Swt.. Namun pengakuan itu terjadi tidak sempurna jika manusia belum menyerahkan diri sepenuhnya kepada Allah dalam bentuk ketaatan kepada segala ketentuan Allah. Inilah yang menyebabkan wajah permasalahan menjadi berbeda di setiap zaman dan tempat. Maka cara penyelesaiannya hanya berbeda wajah tapi bukan beda esensinya.

Salah satu meteri dalam khuruj yang merupakan prinsip jamaah tabligh (enam sifat sahabat), pada urutan pertama disebutkan yakni pada kalimat Laa Illaha Illallah Muhammadur Rasulullah, maksudnya sifat yang paling utama adalah sifat Iman, menafikan seluruh kekuatan makhluk. Mentablighkan kebesaran Allah, dan berpikir bagaimana caranya agar manusia selalu membicarakan kebesaran Allah pada setiap waktu dan tempat hingga hanya Allah-lah yang masuk dalam hati manusia, bukan keberadaan dan segala hal bersifat diniawi (yang hanya sementara). Dengan demikian diharapkan akan timbul rasa ikhlas dalam setiap keputusan Allah, baik dan buruknya.

Penanaman keyakinan ini dimulai dari sejak dini, sehingga anak-anak karkun jamaah tabligh, dapat mengembalikan setiap kejadian dalam konsep kehendak Allah (iradatullah). Dalam menjalankan sunnah nabi, diantaranya mereka melatih anak-anak menghafal doa-doa masnunah, memakai pakaian 
muslim agar terbiasa dan paham akan aurat yang wajib ditutupi dan lain sebagainya.

Penulis melihat hal ini suatu hal yang positif, karena manhaj Qur'ani dalam mendidik manusia ialah dengan memulai dari yang pokok sesuai dengan kaidah ke-enam dalam fiqih dakwah (al-ushul al-furu'), dalam mendidik manusia. Alquran sangat memperhatikan manhaj pendidikan, dengan menjelaskan persepsi Islam. Misalnya tentang hakikat ketuhanan, yaitu dengan mengenalkan manusia kepada Tuhannya dengan secara rinci dan menyeluruh, mengenalkan kepada mereka Dzat-Nya dan sifat-sifatnya, mengenalkan tentang sifat-sifat ketuhanan yang membedakan antara Dia dan hamba-hamba-Nya, sebagaimana mengenalkan kepada mereka tentang pengaruh Allah terhadap alam semesta dan atas diri manusia khususnya. ${ }^{9}$

Pengenalan ini berjalan dengan ruang lingkup yang sangat luas, sebagaimana yang terdapat dalam Alquran dengan manhaj yang khas, sehingga eksistensi Allah benar-banar dapat dirasakan oleh jiwa manusia secara jelas dan nyata. Kemudian mempengaruhi jiwa manusia dari lubuk hatinya, sehingga mereka merasa dekat dan erat hubungan dengan-Nya serta tidak bisa lepas dari pengawasan-Nya, dan tidak pula bisa melupakan-Nya. ${ }^{10}$

Namun bagaimana telah dikemukakan terdahulu bahwa dakwah memiliki cakupan yang amat luas, tidak cukup hanya membicarakan keimanan dan kebesaran Allah saja. Ada banyak hal yang harus disampaikan karena saling keterkaitannya. Alquran tak hanya menjelaskan perkara keimanan (tauhidullah) saja, melainkan lebih luas mencakup semua aspek kehidupan, sebab secara empiris dakwah berhadapan dengan kehidupan manusia itu sendiri. Yaitu manusia dalam kehidupan beragama, manusia dalam kehidupan sosial dan sebagainya, maka dalam setiap aktifitas manusia harus bias dijadikan sebagai alat dakwah.

Jum'ah Amin Abdul Aziz dalam buku fiqih dakwah berpendapat, bahwa Alquran memuat dua bentuk bayan (penjelasan) sebagai berikut: 1). Bayan yang berkaitan dengan dakwah, yaitu mencakup: Tauhid, Penetapan risalah, Adanya Alquran itu dari Allah Swt., Penetapan hari ba'ats, Penjelasan mengenai penyimpangan dan kesesatan yang ada pada umat-umat di masa lalu. 2). Bayan yang memperhatikan sisi syar'i yaitu sesuatu yang menjadi keharusan, seperti uraian tentang hukum-hukum terapan dalam ibadah,

${ }^{9}$ Jum'ah Amin Abdul Aziz, Fiqih ZDakwah, (Solo: Era Intermedia, 2003), hlm., 338

${ }^{10}$ Aziz, Fiqih, hlm., 348 
muamalah, masalah kepribadian, peradaban, politik, peperangan, pokokpokok Negara Islam dan sebagainya. Inilah Alquran yang diturunkan di Madinah. ${ }^{11}$

Pada zaman ini, Islam diserbu dengan berbagai paham kufur, dengan tujuan menghapus kepribadian dan identitas umat dan mencabut nilai-nilai keislaman dari umatnya. Maka sudah saatnya jika dakwah lebih tercurahkan untuk memelihara kaum muslimin dan pemudanya dengan memperkuat akidah dan menyatukan kekuatan mereka untuk melaksanakan kewajibankewajiban yang ada, serta menjauhkan mereka dari melakukan dosa-dosa besar. $^{12}$

Dalam salah satu asas (dasar) jamaah tabligh yaitu melaksanakan amar $m a^{\prime} r u f$ dan tidak atau bukan nahi munkar. Dan juga ushul dakwahnya tentang larangan membicarakan politik baik dalam dan luar negeri, hal ini menunjukkan adanya pembatasan-pembatasan terhadap prinsip dasar, sasaran ataupun prosedur dakwah Islam yang telah ditetapkan, padahal sumua itu telah jelas terisi dalam Alquran dan rasul-Nya.

Sebagai contoh adalah dakwah Rasul setelah hijrah ke Madinah. Rasulullah membangun sebuah pemerintahan yang kuat sebagai salah satu perlindungan misi dakwah Islam, dan hal ini terbukti dengan tersebar luasnya dakwah Islam tak hanya pada masyarakat kalangan Arab saja melainkan menyebar hingga keluar jazirah arab (dakwah struktur). Pemerintah adalah suatu perkara terkait dengan struktur jaringan kekuatan dan kekuasaan yang ada pada suatu negara. Dengan demikian jelas bahwa Rasulullah pun menjadikan kekuasaan sebagai alat dakwah yang ampuh dalam taraf kehidupan sosial lebih luas yakni antar bangsa.

Jamaah Tabligh dinilai termasuk jamaah-jamaah yang mengambil sebagai prinsip dasar dakwah (hanya melaksanakan amar ma'ruf), membatasi sasaran materi (hanya seputar enam sifat sahabat), ia juga menempuh prosedur cukup dengan prosedur khuruj, sebagai akibatnya jamaah Tabligh tidak bisa muncul sebagai jamaah yang reprensentatif untuk mengemban amanah dakwah Islam yang bersifat "Rahmatan Lil a'lamin".

Manhaj jamaah yang mengambil dan menggunakan sebagaimana saja dari petunjuk dan ajaran Islam, tentu tertolak karena melawan kehendak

\footnotetext{
${ }^{11}$ Aziz, Fiqih, hlm., 346

${ }_{12}$ Aziz, Fiqih, hlm., 346
} 


\section{Kamalludin}

syariat. Baginya perlu mengkaji ulang dan mengadakan perbaikan serta ishlah yang benar, sesuai kriteria petunjuk dan kesempatan Islam. Allah Swt. berfirman:

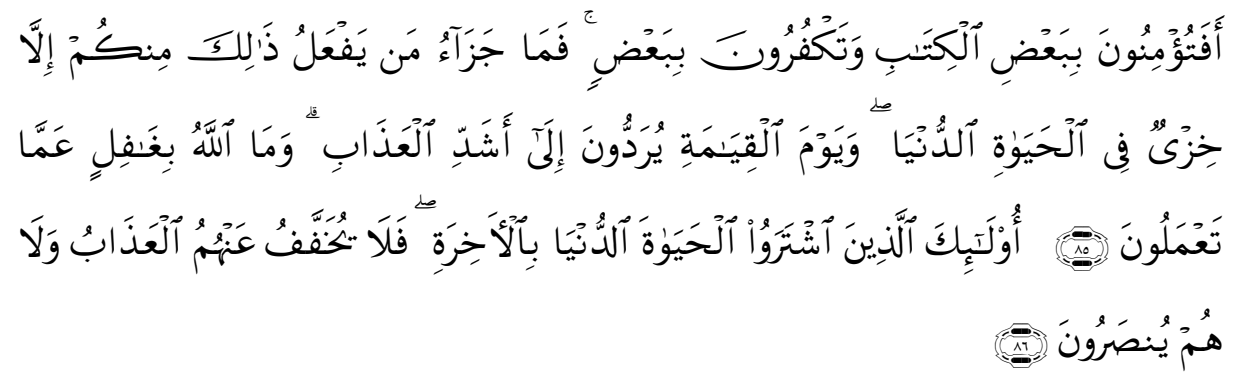

Apakah kamu beriman kepada sebahagian Al kitab (Taurat) dan ingkar terhadap sebahagian yang lain? Tiadalah Balasan bagi orang yang berbuat demikian daripadamu, melainkan kenistaan dalam kehidupan dunia, dan pada hari kiamat mereka dikembalikan kepada siksa yang sangat berat. Allah tidak lengah dari apa yang kamu perbuat. Itulah orang-orang yang membeli kehidupan dunia dengan (kehidupan) akhirat, Maka tidak akan diringankan siksa mereka dan mereka tidak akan ditolong (QS. Al-Baqarah: 85-86).

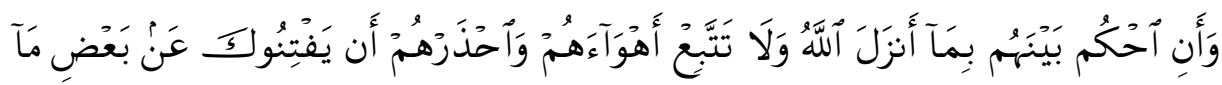

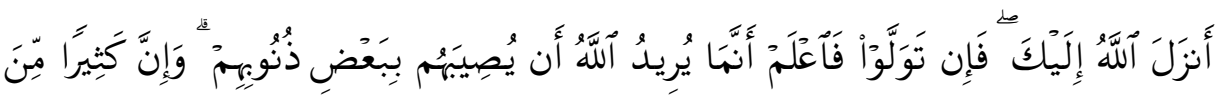
ألنَّاسِ لَفَسِقُونَ

Dan hendaklah kamu memutuskan perkara di antara mereka menurut apa yang diturunkan Allah, dan janganlah kamu mengikuti hawa nafsu mereka. Dan berhati-hatilah kamu terhadap mereka, supaya mereka tidak memalingkan kamu dari sebahagian apa yang telah diturunkan Allah kepadamu. Jika mereka berpaling (dari hukum yang telah diturunkan Allah), Maka ketahuilah bahwa Sesungguhnya Allah menghendaki akan menimpakan musibah kepada mereka disebabkan sebagian dosa-dosa mereka. Dan Sesungguhnya kebanyakan manusia adalah orang-orang yang fasik (QS. Al-Maidah: 49).

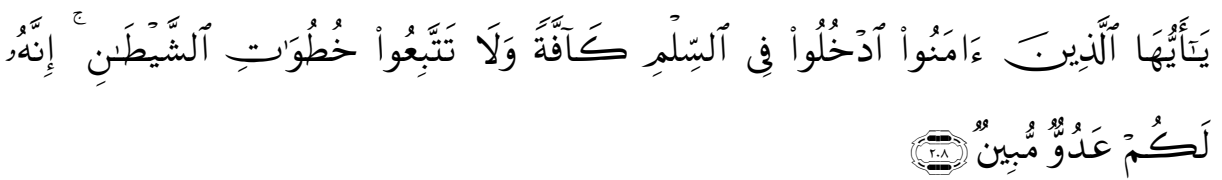


Hai orang-orang yang beriman, masuklah kamu ke dalam Islam keseluruhan, dan janganlah kamu turut langkah-langkah syaitan. Sesungguhnya syaitan itu musuh yang nyata bagimu (QS. Al-Baqarah: 208).

Jadi selayaknya mereka tidak menilai bahwa mendakwahkan selain keimanan dan penerapan sunnah nabi sehari-hari, merupakan pembicarakan yang sia-sia, karena sesungguhnya hal-hal diluar itu sebenarnya pernah dicontohkan rasul. Apalagi pada masa sekarang, dakwah dituntut lebih jeli dan luwes memanfaatkan segala cara dan media, agar dapat menyentuh dan diterima oleh semua golongan, tentunya tetap sesuai koridor yang ditetapkan Islam, karena sesungguhnya semua perkara dalam Islam adalah saling terkait satu sama lainnya (waqi'iyah dan syumuliyah).

Quraish Shihab dalam bukunya "membumikan Al-Qur'an” menulis: dari sejarah diturunkannya Alquran, dapat diambil kesimpulan bahwa Alquran mempunyai tiga tujuan pokok:

Pertama; Petunjuk akidah dan mempercayakan yang harus dianut oleh manusia yang tersimpul dalam keimanan akan keesaan Tuhan dan kepercayaan akan kepastian adanya hari pembalasan.

Kedua; Petunjuk mengenai akhlak yang murni dengan jalan menerangkan norma-norma keagamaan dan susila yang harus diikat oleh manusia dalam kehidupannya secara individual atau kolektif.

Ketiga; Petunjuk mengenai syariat dan hukum dengan jalan menerangkan dasar-dasar hukum yang harus diikuti oleh manusia dalam hubungannya dengan Tuhan dan sesamanya, atau dengan kata lain yang lebih singkat, "Alquran adalah petunjuk bagi seluruh manusia ke jalan yang harus ditempuh demi kebahagiaan hidup di dunia dan di akhirat."13

\section{Antara Dakwah dan Keluarga}

Keluarga adalah jiwa masyarakat dan tulang punggungnya, kesejahteraan lahir dan batin yang dinikmati oleh suatu bangsa atau sebaliknya, kebodohan dan keterbelakangannya adalah cerminan dari keadaan keluarga-keluarga yang hidup pada masyarakat bangsa tersebut. ${ }^{14}$

\footnotetext{
${ }^{13}$ M. Quraisy Shihab, Membumikan Al-Qur'an, (Bandung: Mizan, 1996), hlm., 40.

14 Shihab, Membumikan, hlm., 253.
} 
Menurut Cahyadi Takariawan keluarga atau rumah tangga Islami adalah rumah tangga yang di dalamnya adab-adab Islam, baik yang menyangkut individu maupun keseluruhan anggota rumah tangga. Lebih lanjut ia mengatakan keluarga Islami adalah "sebuah rumah tangga yang didirikan diatas landasan ibadah. Mereka bertemu dan berkumpul karena allah, saling menasehati dalam kebenaran dan kesabaran, serta saling menyuruh kepada yang ma'ruf dan mencegah dari yang munkar, karena kecintaan mereka kepada Allah."15 Oleh karena itu pembinaan keluarga dalam rangka membentuk rumah tangga Islami merupakan tanggung jawab seorang suami sebagai pemimpin rumah sebagaimana ketetapan Allah "Arrijalu qowwamuna 'alan nisaa.

Kebaradaan lembaga keluarga telah diakui di seluruh penjuru dunia dan eksistensinya tidak dapat dihilangkan atau digantikan dengan institusi lain dalam menegakkan bangunan masyarakat. Melihat dari tujuannya, menurut Didin Hafidhuddin mengutip dari Jalaluddin Rahmat juga memberikan beberapa fungsi berkeluarga kepada beberapa bagian. Dan salah satu fungsi tidak bisa dipisahkan dari yang lainnya, karena saling terkait dan apabila terpisahkan maka akan menimbulkan ketidak harmonisnya keluarga sebagai media dan tempat pembinaan kepribadian anggota keluarga tersebut. Diantara fungsi-fungsi tersebut adalah:

Pertama; Fungsi afektif dan reproduksi, yaitu keluarga memberikan kasih sayang yang bisa melahirkan keturunan.

Kedua; Fungsi religious, yaitu keluarga memberikan pangalaman dan pendidikan keagamaan kepada anggota-anggotanya. Karena terjadinya perubahan kepribadian dan tingkah laku tergantung kepada yang membawanya, dan disini peran orang tua sangat dominan. Kebiasaankebiasaan keagamaan hendaknya ditanamkan sedini mungkin.

Ketiga; Fungsi rekreatif, yaitu keluarga merupakan pusat rekreasi yang menyenangkan bagi anggotanya. Disinilah perlunya menciptakan suasana yang menyenangkan dan betah untuk tinggal di rumah.

Keempat; Fungsi protektif, yaitu keluarga melindungi anggotaanggotanya dari rasa takut dan khawatir baik ancaman fisik maupun

${ }^{15}$ Cahyadi Takariawan, Penik-penik Rumah tangga Islami, Tatanan dan Peranannya Dalam Masyarakat, (Surakarta: Era Intermedia, 2001), hlm., 36. 
psikisional. Keluarga juga merupakan tempat untuk memecahkan permasalahan yang terjadi pada anggota-anggotanya.

Kelima; Fungsi edukatif, yaitu keluarga bisa memberikan nilai-nilai pendidikan kepada anggotanya, terutama sekali anak-anaknya. Orang tua yang baik adalah orang tua yang memposisikan sebagai figur sentral pendidikan dalam keluarga.

Keenam; Fungsi sosial, yaitu keluarga merupakan tempat terjadinya proses sosialisasi nilai-nilai yang berlaku dalam masyarakat, sekaligus juga memberikan prestise dan status kepada anggotanya. ${ }^{16}$

Sebuah keluarga akan harmonis dan kokoh, apabila seluruh fungsi dan tujuan berkeluarga tercapai, karena menurut pandangan Islam berkeluarga bukan saja dipandang sebagai hubungan dua insan yang berlainan jenis, akan tetapi lebih jauh dari itu, Islam memandang rumah tangga sebagai amanah dan tanggung jawab besar.

Meninggalkan keluarga untuk khuruj, bila dilakukan dalam bilangan lama seperti 40 hari, empat bulan ataupun setahun, menurut penulis bisa mengabaikan salah satu fungsi dalam keluarga yakni pada pembinaan dan pemeliharaan kesejahteraan (lahir dan batin) keluarga.

Pembinaan keluarga menitik beratkan pada empat faktor yakni; aspek keagamaan, aspek pendidikan, aspek kesehatan dan aspek ekonomi.

a. Aspek Keagamaan

Aspek ini yang terpenting dan utama dalam membina keluarga, aspek ini terdiri dari aqidah, ibadah dan akhlak. Peranan orang tua amat besar dalam pembinaan hal ini dapat dilihat dari sabda Rasulullah sebagai berikut:

$$
\text { كل من مولود يولد على الفطرة فابواه يهودانه اوينصرانه ........ }
$$

"Tiada ada seorangpun kecuali dilahirkan dalam keadaan fitrah, maka kedua orang tuanyalah yang menjadikannya Yahudi dan Nasrani .." (HR. Bukhari)

b. Aspek Pendidikan

Orang tua seharusnya menjadi figur teladan dalam kesehariaannya yang dilihat langsung oleh anak mereka. Ia juga harus benar-benar memberikan dan memperhatikan aspek pendidikan bagi anak-anaknya. Yang

16 Didin Hafidhuddin, Dakwah Aktual, (Jakarta: Gema Insani Press, 2001), hlm. 161. 


\section{Kamalludin}

dimaksud pendidikan di sini adalah menumbuhkan dan mengembangkan serta meningkatkan segi jasmani anak yang bersifat fisik, dan segi rohani (mental) anak yang berupa potensi-potensi positif yang ada pada dirinya seperti kebaikan, intelektual, bakat dan lain-lain. Pendidikan adalah anggotaanggota keluarga yang lebih tua dari anak. Dan dari pelaksanaan pendidikan tersebut tak akan mencapai hasil yang maksimal bila hanya melalui dogma (ajaran), tutur kata atau nasehat semata. Akan tetapi harus juga dilakukan melalui diskusi yang melibatkan akal pikiran dan teladan yang baik.

c. Aspek Kesehatan

Yakni sehat jasmani dan rohani. Salah satu upaya dalam rangka pembinaan aspek kesehatan jasmani adalah makanan yang bergizi, yang dalam istilah Islam disebut halal dan thayyib.

Adapun kesehatan mental menurut Islam bersumber dari hati, maka pendekatan adama adalah bentuk dari upaya memelihara kesehatan mental dengan taqarrub kepada Allah S.W.T, sebagaimana firman Allah Azza Wajalla:

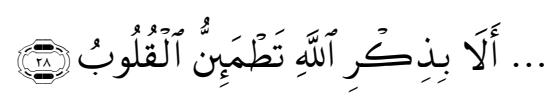

Ingatlah, hanya dengan mengingat Allah-lah hati menjadi tenteram. (QS. Ar $\left.\mathrm{Ra}^{\prime} \mathrm{du}: 28\right)$

\section{d. Aspek Ekonomi}

Aspek ekonomi adalah salah satu aspek yang penting dibina secara intensif dalam keluarga. Karena sebagian besar keluarga muslim di negara kita adalah amat lemah dalam bidang ekonomi. Padahal Allah telah memberi ultimatum pada keluarga muslim dalam firman-Nya:

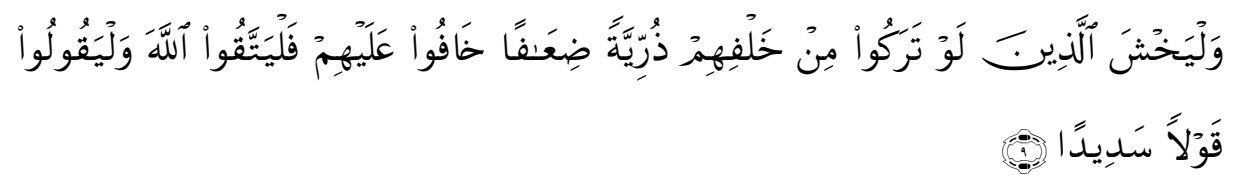

"dan hendaklah takut kepada Allah orang-orang yang seandainya meninggalkan di belakang mereka anak-anak yang lemah, yang mereka khawatir terhadap (kesejahteraan) mereka. Oleh sebab itu hendaklah mereka bertakwa kepada Allah dan hendaklah mereka mengucapkan perkataan yang benar" (QS. An-Nisa: 9). 
Salah satu pembinaan aspek ekonomi ialah mendidik anak-anak dengan pendidikan yang tinggi dan berkualitas, baik pendidikan nilai agama, intelektual maupun keterampilan. Selain itu orang tua juga harus memberikan teladan dengan giat dan disiplin dalam kerja agar dapat meningkatkan ekonomi keluarga.

Keempat aspek ini perlu pendapat perhatian dan konsisten. Karena mengingatkan realitas kehidupan masyarakat muslim yang begitu kompleks saat ini, mereka dihimpit oleh sejumlah problem yang amat memperihatinkan, kehampaan iman, kebodohan, rendahnya kesehatan, kemiskinan dan sebagainya. Semua ini perlu penanganan yang nyata dan butuh kerja keras semua elemen termasuk sebuah rumah tangga yang merupakan unit terkecil dalam elemen sosial. Jangan sampai terwujud di lingkungan keluarga kita kekafiran, karena kemiskinan yang menjeratnya.

Jika terabaikan oleh seorang karkun, akan berdampak kurang baik, karena ketika ia meninggalkan keluarga, banyak hal akan terjadi dalam keseharian keluarga tersebut, dan amat membutuhkan tanggung jawab serta perlindungan seorang suami, contoh; ketika anggota keluarga tersebut ditimpa musibah, sementara dalam waktu bersamaan, ketidakhadiran kepala keluarga yang diharapkan dapat bertanggung jawab sepenuhnya baik materi dan immateri (dukungan, perhatiaan dan sebagainya) tidak dipenuhi. Maka dalam banyak kasus sering ditemui seorang istri karkun harus berupaya meminta bantuan pada tetangganya atau keluarganya yang lain, hal ini mengesankan seorang suami lepas tanggung jawab pada problem rumah tangga dan tentu akan menjadi gambaran (image) buruk pada masyarakat.

Fenomena semacam ini menurut penulis tidak sesuai dengan apa yang diajarkan oleh Islam. Karena hal ini akan menyulitkan seorang istri dan bahkan bisa menyempitkan hati mereka Allah S.W.T berfirman:

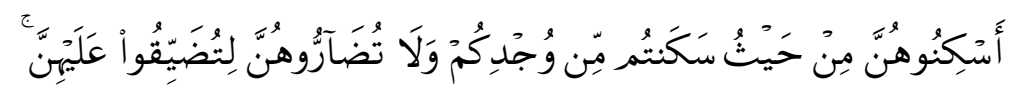

Tempatkanlah mereka (para isteri) di mana kamu bertempat tinggal menurut kemampuanmu dan janganlah kamu menyusahkan mereka untuk menyempitkan (hati) mereka (QS. At-Thalaq: 6).

Allah Swt. berfirman:

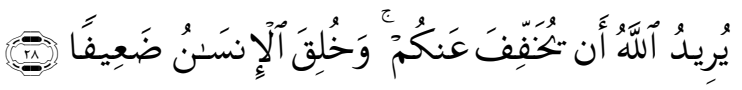




\section{Kamalludin}

Allah hendak memberikan keringanan kepadamu, dan manusia dijadikan bersifat lemah (QS. An-Nisa: 28).

Bukankah seorang suami harus bersikap yang terbaik dengan perhatiaan, kasih sayang dan lembut bagi keluarganya? Sebagaimana Allah Swt. berfirman:

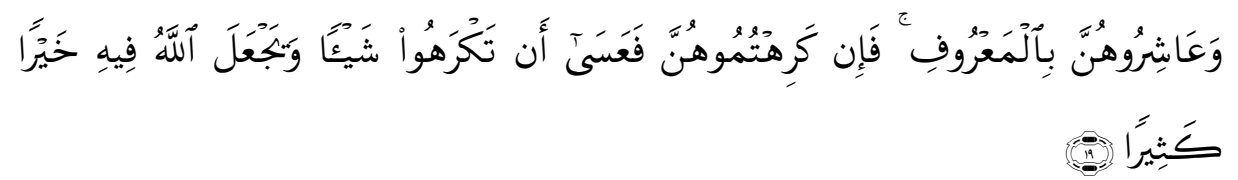

Hai orang-orang yang beriman, tidak halal bagi kamu mempusakai wanita dengan jalan paksa dan janganlah kamu menyusahkan mereka karena hendak mengambil kembali sebagian dari apa yang telah kamu berikan kepadanya, terkecuali bila mereka melakukan pekerjaan keji yang nyata. Dan bergaullah dengan mereka secara patut. Kemudian bila kamu tidak menyukai mereka, (maka bersabarlah) karena mungkin kamu tidak menyukai sesuatu, padahal Allah menjadikan padanya kebaikan yang banyak. (QS. An-Nisa: 19).

Mua'syarah bi al-Ma'ruf dalam hal-hal yang berkaitan dengan kemanusiaan, suami dan istri harus saling menghargai dan menghormati. Masing-masing harus berlaku sopan, saling menyenangkan, tidak boleh saling menyakiti atau memperlihatkan kebencian dan tidak boleh pula saling mengungkap-ungkap jasa baiknya. ${ }^{17}$

Rasulullah Saw. menegaskan dalam sabdanya:

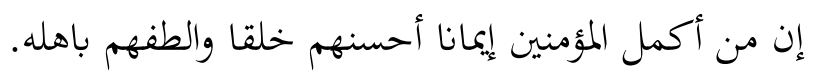

Sesengguhnya orang mukmin yang paling sempurna imannya adalah yang paling mulia akhlaknya dan paling lemah lembut kepada keluarganya (HR. Tirmidzi dan Hakim)

Seorang kepala rumah tangga harus berjiwa besar, senantiasa lembut terhadap keluarganya, memperlakukan seorang istri secara layak sesuai dengan fitrah wanita (lemah) serta menciptakan kedekatan dengan istrinya dan berusaha membuat istrinya terhindar dari kesusahan hatinya.

Demikian sebabnya (sifat lemah istri) mengapa kewajiban nafkah disebabkan kepada sorang suami, sebagaimana Allah Swt. berfirman:

${ }_{17}$ KH. Husein Muhammad, Fiqih Perempuan Refleksi Kiai atas Wawancara Agama dan Gender, (Yogyakarta: LKiS Yogtakarta, 2001), hlm., 114. 


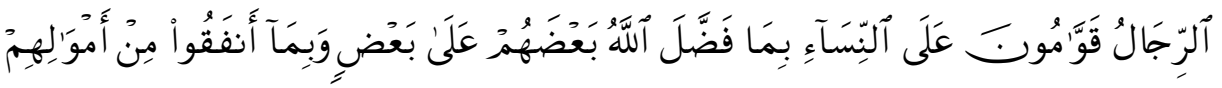

Kaum laki-laki itu adalah pemimpin bagi kaum wanita, oleh karena Allah telah melebihkan sebagian mereka (laki-laki) atas sebagian yang lain (wanita), dan karena mereka (laki-laki) telah menafkahkan sebagian dari harta mereka (QS. An-Nisa: 34).

Menegaskan ayat diatas, Rasulullah menyatakan:

$$
\text { ..... . الرجال راع في أهله وهو مسئول عن رعيته ... }
$$

“... dan soerang laki-laki (suami/ayah) adalah penanggung jawab keluarganya, dan dia akan dimintai pertanggungjawaban atas kepemimpinannya..." (HR. Bukhari dan Muslim).

Nafkah itu bermacam-macam sesuai kebutuhan wanita: bisa berupa makanan, tempat tinggal, pelayanan (perhatian), pengobatan, dan pakaian meskipun wanita itu kaya. ${ }^{18}$ Tentu pemberian nafkah ini sesuai batasan syariat yakni tidak berlebihan dan tidak terlalu minim sesuai kadar kemampuan suami.

\section{Hak dan Kewajiban Wanita Mencari Ilmu Pengetahuan}

Dalam Islam, ilmu pengetahuan keagamaan itu wajib hukumnya untuk setiap Muslim laki-laki dan perempuan. Oleh karena itu ilmu pengetahuan, secara umum amat dijunjung tinggi dan dihormati dalam Islam. Penghormatan yang tinggi terhadap ilmu dan terhadap orang yang memilikinya nampak jelas dalam Alquran Allah Swt. berfirman:

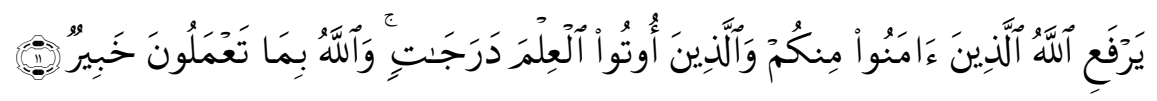

Allah akan meninggikan orang-orang yang beriman di antaramu dan orangorang yang diberi ilmu pengetahuan beberapa derajat. Dan Allah Maha mengetahui apa yang kamu kerjakan. (QS. Al-Mujadalah: 11).

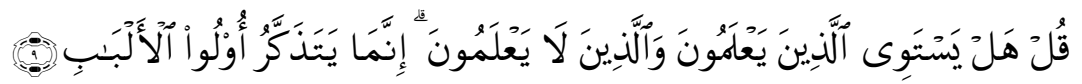

${ }^{18}$ Abdul hamid Kisyik, Bimbingan Islam untuk Mencapai Keluarga Sakinah, (Bandung: AlBayan, 1995), hlm., 128 


\section{Kamalludin}

"Adakah sama orang-orang yang mengetahui dengan orang-orang yang tidak mengetahui?" Sesungguhnya orang yang berakallah yang dapat menerima pelajaran. (QS. Az-Zumar: 9).

Allah Swt. telah menghubungkan kesaksian-Nya dan kesaksian para malaikat dengan kesaksian orang-orang yang berilmu. Ini sebenarnya merupakan keistimewaan dan bukti keunggulan orang yang berilmu.

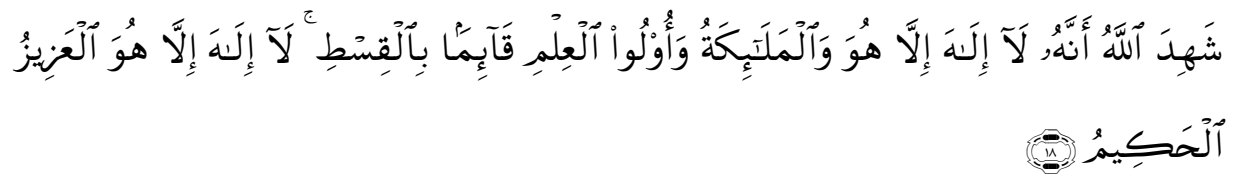

Allah menyatakan bahwasanya tidak ada Tuhan melainkan Dia (yang berhak disembah), yang menegakkan keadilan. Para Malaikat dan orang-orang yang berilmu (juga menyatakan yang demikian itu). Tak ada Tuhan melainkan Dia (yang berhak disembah), yang Maha Perkasa lagi Maha Bijaksana (QS. Ali Imran: 18).

Ayat yang pertama yang diwahyukan kepada Rasul Saw juga menekankan pentingnya Ilmu pengetahuan:

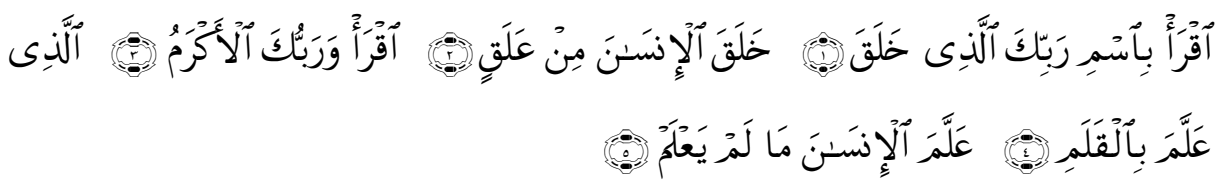

Bacalah dengan (menyebut) nama Tuhanmu yang Menciptakan, Dia telah menciptakan manusia dari segumpal darah. Bacalah, dan Tuhanmulah yang Maha pemurah, yang mengajar (manusia) dengan perantaran kalam, Dia mengajar kepada manusia apa yang tidak diketahuinya (QS. Al-Alaq: 1-5).

Ayat-ayat ini diwahyukan untuk menetapkan pokok-pokok agama berdasarkan ilmu pengetahuan, dan juga menegaskan pentingnya pengetahuan agama. Karena itu kata pertama yang diwahyukan dan diucapkan oleh malaikat Jibril adalah "Bacalah". Membaca adalah kunci menuju ilmu pengetahuan dan karena tulisan melengkapi bacaan, maka Allah Swt. menyoroti perbuatan ini dengan mengatakan, "mengajar dengan kalam." Kalam (pena) dari dulu hingga sekarang tetap merupakan alat yang paling berguna dan digunakan untuk menyampaikan dan memelihara ilmu pengetahuan. Dan telah meninggalkan dampaknya pada umat manusia selama berabad-abad. ${ }^{19}$

${ }^{19}$ Sayyid Quthub, Fi Dzilal Al-Qur'an, Jilid 6, hlm., 3932. 
Suatu kenyataan yang tidak bisa dipungkiri bahwa Islam meliputi ibadah, akhlak, politik, sosiologi, ekonomi dan hukum yang mengurusi berbagai persoalan kehidupan sehari-hari. Semua pengetahuan itu tidak dapat diperoleh secara otomatis, melainkan melalui proses pengkajian, belajar dan mengajar. Islam adalah agama yang luas, beragam, komperhensif, dan terinci. ${ }^{20}$

Selain itu, kaum perempuan mewakili separuh masyarakat kosekuensinya, mereka bersama-sama dengan kaum laki-laki memikul tanggung jawab pribadi dan masyarakat yang membutuhkan pendidikan yang baik dan ilmu pengetahuan yang cukup untuk memenuhi kebutuhan individu dan bangsa Islam yang sedang tumbuh. ${ }^{21}$

Seorang wanita (ibu) dalam jamaah tabligh selalu diprioritaskan lebih banyak waktunya untuk tinggal (diam) di rumah mengurus semua urusan rumah tangga. Dan jika ia menurut ilmu agama maka cukup dari suaminya ataupun melalui cara lain yang sekitarnya ia tak sampai meninggalkan rumah. Salah satunya yaitu menghidupkan majlis ta'lim rumah dengan membaca kitab Fadhail A'mal. Majlis ta'lim tersebut adalah pintu untuk masuknya agama ke dalam rumah. ${ }^{22}$ Intinya ialah seakan ada pembatasan bagi seorang wanita menimba ilmu yakni cukup ilmu agama dan ilmu yang terkait dengan manajemen rumah tangga serta keterampilan keibuan. Seakan ilmu tersebut mencukupi untuk mengatasi berbagai persoalan kelak dalam perjalanan bahtera rumah tangga.

Demikian pula ketika aktifitas khuruj dalam bentuk masturah (dilakukan oleh para istri/gadis jamaah tabligh) mereka lebih banyak mengisi waktu untuk menuntut ilmu seputar muzakarah 6 sifat, membaca kitab Fadhail Amal dan mempelajari adab-adab sunnah nabi. Terlarang bagi mereka mempelajari ilmu lainnya untuk memperluas cakrawala pengetahuan yang tidak terbatas.

Melihat fenomena diatas tentu memprihatikan kita sebagai muslimah, karena ilmu pengetahuan baik agama (ilmu wajib) dan ilmu umum seperti

${ }^{20}$ Fatimah Umar Nasif, Menggugat sejarah Perempuan: Mewujudkan Idealisme Gender Sesuai Tuntunan Islam, terj. Burhan Wirasubrata dan Kundan D. Nuryakien, (Jakarta: Cendekia Sentra Muslim, 2001), hlm., 101.

${ }^{21}$ Nasif, Menggugat, hlm., 102.

22 Maulana Muhammad Manshur, Masturah: Usaha Dakwah di Kalangan Wanita, (Bandung: Pustaka Ramadhan, 2001), hlm., 6. 


\section{Kamalludin}

kesehatan, politik, pendidikan, ekonomi, budaya dan sebagainya selama bersifat positif amatlah dianjurkan oleh Islam, ilmu membawa kaum perempuan dari kebodohan dan kesempitan pola pikir kepada cakrawala pengetahuan yang luas dan bercahaya. Dengan memiliki berbagai pondasi ilmu, mereka bisa memahami mekanisme kehidupan sehari-hari dan juga mereka akan sanggup membantu anak-anaknya dalam studi kelak. Hal ini penting karena ibulah yang bertanggung jawab atau pendidikan anakanaknya di rumah. Namun perlu diingat, menurut ilmu bagi kaum perempuan dengan tanpa mengorbankan kesederhanaan dan kehormatan mereka, serta tidak melanggar syariat seperti; tidak memakai wangi-wangian, tidak untuk pamer kecantikan, harus jauh dari laki-laki dan tidak campur dengan laki-laki.

Dahulu, para sahabat perempuan mengetahui dan mengerti pentingnya ilmu pengetahuan menurut Islam, dengan penuh gairah mereka berlomba di tengah kaumnya, dan berusaha keras mendapatkan pengetahuan yang benar. Nabi Saw. mendorong antusiasme mereka dan mengizinkan mereka untuk menghadiri majlis ilmunya. Karena Allah Swt. telah mengajarinya untuk mengatakan:

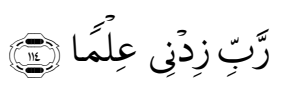

"Ya Tuhanku, tambahkanlah kepadaku ilmu pengetahuan." (QS. Thaha: 114).

Mereka memahami riwayat ini ditujukan kepada laki-laki dan perempuan muslim dan tidak khusus kepada laki-laki sebagaimana diyakini oleh sebagian orang. Mereka mencari pengetahuan yang benar dan berlomba di tengah kaumnya untuk melakukan amal saleh. Allah Swt. berfirman:

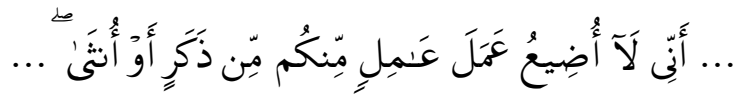

"Sesungguhnya aku tidak menyia-nyiakan amal orang-orang yang beramal di antara kamu, baik laki-laki atau perempuan (QS. Ali Imran: 195).

Sejarah membuktikan bahwa banyak wanita yang menonjol pengetahuannya bahkan menjadi rujukan sekian banyak tokoh laki-laki, seperti Aisyah istri Rasulullah Saw., Sayidah Sakinah Putri Husein bin Ali, kemudian Al-Syaikhah Suhrah yang bergelar "Fakhr al-Nisa" (kebanggaan perempuan), ia adalah salah seorang guru Imam Syafe'i.

Dalam hal ini Syeikh Muhammad Abduh berpendapat: 
"Kalaukah kewajiban perempuan mempelajari hukum-hukum akidah kelihatannya amat terbatas, sesunggguhnya kewajiban mereka untuk mempelajari hal-hal yang berkaitan dengan rumah tangga, pendidikan anak, dan sebagainya, merupakan persoalan-persoalan duniawi (dan yang berada sesuai dengan perbedaan waktu, tempat dan kondisi) jauh lebih banyak dari pada soal-soal akidah keagamaan." 23

\section{Penutup}

Berdasarkan uraian yang telah dipaparkan terdahulu, maka penulis mengambil kesimpulan sebagai berikut:

Pertama; Khuruj merupakan sebuah bentuk metode dakwah yang digunakan oleh Jamaah Tabligh. Khuruj adalah perjalanan dakwah dalam upaya membentuk sifat imaniyyah secara bertahap. Khuruj menetapkan bilangan yang harus ditempuh oleh seorang karkun yaitu minimal 3 hari dalam setiap bulan, 40 hari dalam setiap tahun dan 4 bulan dalam seumur hidup, bilangan-bilangan tersebut tidak mengikat, karena biasanya mereka (karkun) selain diberi tasykil (dibujuk) untuk meluangkan waktu di jalan Allah (khuruj) semaksimal kemampuan mereka. Dalam khuruj terdapat asasasas dan ushul-ushul dakwah yang harus ditaati. Di antaranya menetapkan amar ma'ruf bukan nahi munkar dan dan tidak membicarakan politik. Dalam prinsip dakwah islamiyah, menganjurkan kebaikan dan mencegah kemunkaran merupakan prinsip dasar dakwah yang tak terpisahkan karena amar ma'ruf dan nahi munkar sama-sama bertujuan menjadikan manusia beriman dan bertakwa kepada Allah Swt.. Adanya pemisah prinsip ini merupakan pembatas prinsip dakwah di luar kehendak syariat yang telah ditetapkan Allah Swt.. Sebagaimana Khalifah Abu Bakar Shiddiq ra. Tidak menerima suku-suku bangsa Arab yang mau mengucapkan syahadat, mengerjakan shalat lima waktu, tanpa mau mengeluarkan zakat. Salah satu karakter dakwah Islam adalah syumuliyyah yaitu menyeluruh dan sempurna. Jika terkait dengan dakwah berarti tidak memisah-misahkan prinsip-prinsip dakwah yang telah tertera dalam Alquran dan hadits serta menjadikan manhaj (sistem dan metode) nabawi sebagai contoh dalam mengaplikasikan dakwah.

Kedua; Hal positif yang bisa didapat dalam khuruj diantaranya melatih diri untuk meluruskan akidah tauhid dan memantapkan keimanan pada Allah Swt., mengambil keuntungan dari dakwah sebagaimana yang banyak

${ }^{23}$ M. Quraish Shihab, Wawancara Al-Qur'ana, (Bandung: Mizan, 1996), hlm., 309 


\section{Kamalludin}

terjadi pada da'i kita) semata-mata untuk Allah, belajar berkhidmat pada sesama muslim, dan belajar meningkatkan penghormatan pada semua muslim terutama tamu.

Ketiga; Adapun hal negatif yang berdampak kurang baik terhadap kurang baik terhadap keluarga, yaitu pelaksanaan khuruj dalam keadaan kondisi keluarga tidak memungkinkan seperti ekonomi keluarga yang kurang mapan, psikologis keluarga yaitu mental keluarga yang ditinggalkan, kondisi keamanan keluarga dan sebagainya. Islam menganjurkan keseimbangan (wasathiyah), demikian halnya dalam berdakwah, sekecil apapun dakwah yang dilakukan dengan konsisten serta tidak melalaikan kewajiban dan tanggung jawab pada keluarga, maka sebenarnya itulah esensi Islam. Keluarga merupakan mad'u terdekat yang pertama kali harus diperhatikan, baik pembinaan dan kesejahteraan. Oleh karena itu selayaknya seorang yang ingin berjuang dalam jalan dakwah, hendaknya ia terlebih dahulu mempersiapkan kondisi keluarga (dari berbagai faktor) dengan sebaikbaiknya, agar tidak menimbulkan masalah ataupun konflik pada keluarga kelak. Di samping itu diharapkan kehidupan keluarga sakinah biasa dijadikan panutan bagi mad'unya (masyarakat luas) kelak.

\section{Pustaka Acuan}

al-Jarbu, Nizar bin Ibrahim, Peringatan Penting Terhadap Jamaah Tabligh, terj, Arif Mufid, Surakarta: Yayasan al-Madinah, 1998.

Aziz, Jum'ah Amin Abdul, Fiqih ZDakwah, Solo: Era Intermedia, 2003.

Hafidhuddin, Didin, Dakwah Aktual, Jakarta: Gema Insani Press, 2001.

Ishaq, An Nadhr M., Khuruj Fi Sabilillah, Sarana Tarbiyah Ummat Untuk Membentuk Sifat Imaniyyah, Bandung: Al-Ishlah Press, tt.

Kisyik, Abdul hamid, Bimbingan Islam untuk Mencapai Keluarga Sakinah, Bandung: Al-Bayan, 1995.

Manshur, Maulana Muahammad, Masturah, Usaha Dakwah di Kalangan Wanita, Bandung: Pustaka Ramadhan, 2001.

Mansyur, Maulana Muhammad, dan Mufti Rusyn Syah Qasimi, Mutiara Nasihat Maulana Ilyas dan Maulana Yusuf, Bandung: Pustaka Ramadhan, 2004. 
Muda, M. Iskandar, Wawancara Langsung, 26 maret 2012

Muhammad, KH. Husein, Fiqih Perempuan Refleksi Kiai atas Wawancara Agama dan Gender, Yogyakarta: LKiS Yogtakarta, 2001.

Nasif, Fatimah Umar, Menggugat sejarah Perempuan: Mewujudkan Idealisme Gender Sesuai Tuntunan Islam, terj. Burhan Wirasubrata dan Kundan D. Nuryakien, Jakarta: Cendekia Sentra Muslim, 2001.

Quthub, Sayyid, Fi Dzilal Al-Qur'an, Jilid 6.

Shihab, M. Quraish, Membumikan Al-Qur'an, Bandung: Mizan, 1996.

Shihab, M. Quraish, Wawancara Al-Qur'ana, Bandung: Mizan, 1996.

Takariawan, Cahyadi, Penik-penik Rumah tangga Islami, Tatanan dan Peranannya Dalam Masyarakat, Surakarta: Era Intermedia, 2001. 